\title{
在宅酸素療法患者の外出を支援する追従型搬送移動体の開発
}

\author{
遠 藤 立*1 谷 篤*1 福 島 $\mathrm{E}$. 文 彦*1 \\ 広 瀬 茂 男*1 入部 正 継*2 田窪 敏 夫*3
}

\section{Development of a Leader-following Mobile Robot to Support Home Oxygen Therapy Patients}

\author{
Gen Endo*1, Atsushi Tani*1, Edwardo F. Fukushima*1, \\ Shigeo Hirose ${ }^{* 1}$, Masatsugu Iribe ${ }^{* 2}$ and Toshio Takubo*3
}

\begin{abstract}
Home oxygen therapy (HOT) is a medical treatment for patients suffering from severe lung diseases. Although a walk in an outdoor environment is recommended for the patients to keep physical strength, patients always have to carry a portable oxygen supplier which is not sufficiently light weight for the patients. Our ultimate goal is to develop a mobile robot carrying an oxygen tank and follows a foregoing patient in an urban outdoor environment. We have proposed a mobile robot with a tether interface to detect the relative position of the foregoing patient. In this paper, we improve mobile platform mechanisms and active wheels to maximize the negotiating step height, and to allocate sufficient luggage area in the main body carrying an actual oxygen tank. The following control algorithm is also improved and demonstrate its effectiveness in an outdoor following experiment.
\end{abstract}

Key Words: Mobile Robot, Leader-following, Hyper-tether, Home Oxygen Therapy

\section{1. は じめに}

在宅酸素療法 (Home Oxygen Therapy, HOT) とは慢性閉塞 性肺疾患 (Chronic Obstructive Pulmonary Disease, COPD) に代表される重篤な肺疾患により肺機能が低下した患者に処方 される治療法である. 主に鼻からカニューラと呼ばれるチューブ で高濃度の酸素を吸入することで血中の酸素濃度を高くし，息 切れなどの諸症状を緩和することができる，特に自宅に酸素濃 縮器を設置したり，外出時に酸素ボンべを携帯したりすること で，入院することなく日常生活の質を保ったまま加療を続ける ことができる利点がある，機器のメインテナンス・レンタルを 行う事業者・保険などの枠組みもすでに整っており, 現在日本 で 15 万人以上に処方されている.

COPD の治療には体力の維持を目的として適度な運動が有効 であり, 散歩などが推奨されている. Fig. 1 に現在外出時に広 く用いられている搬送用カートと携帯用酸素機器を示す. カー 卜内部には酸素ボンベとそのレギュレータに加えて, 吸気時の

原稿受付 2011 年 12 月 9 日

*1 東京工業大学

$* 2$ 大阪電気通信大学

$* 3$ 東京女子医科大学

${ }^{* 1}$ Tokyo Institute of Technology

${ }^{* 2}$ Osaka Electro-Communication University

${ }^{* 3}$ Tokyo Women's Medical University

ロ 本論文は提案性で評価されました。

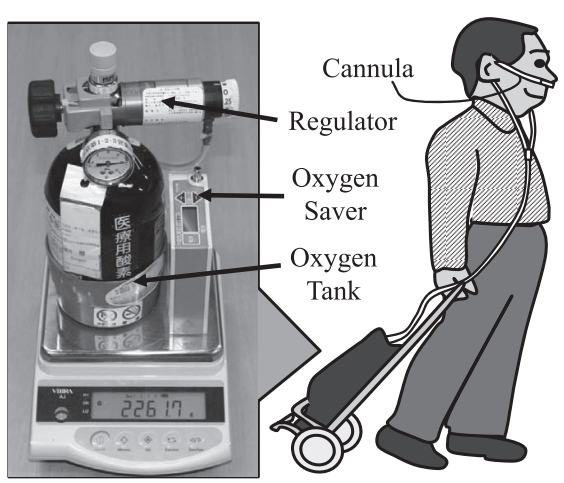

Fig. 1 Portable oxygen supplier

負圧を感知した場合にだけ酸素を供給するための酸素節約装置 が納められている。しかしながら Fig. 1 左に示すように, 現行 の酸素機器は必ずしも軽量ではなく，搬送用カートと合わせる と抢よそ $4[\mathrm{~kg}]$ の質量となる。 カートの運搬は坂道などでは肺 機能に負担をかけるだけでなく，「常にボンべを運搬していなけ ればならない」という心理的負担もあり，その結果，家に引き こもりがちになる患者も少なくない.

最も直接的な解決策の一つは, もちろん現行機器の小型軽量化 であろう，近年の携帯用酸素ボンべはアルミ合金やガラス FRP, カーボン FRP の採用により従来のスチール製容器に比して半 分以下の軽量化を遂げている。. また充填圧力を現行の 150 気圧 
から 200 気圧に上げることでより長時間利用が可能になるよう 開発が続けられている。このような努力にもかかわらず, 現行 の携帯用酸素機器に対し改良すべきとの声は患者の半数以上で あり，携帯性の向上や軽量化が最も望まれている $[1]$.

そこで本研究では, 酸素機器などの重量物を搬送することに 目的を絞り，移動ロボットによる介助を提案し，検討して行く． 本研究の最終目的は, 屋外歩道環境を先導する患者に追従しな がら酸素機器を搬送することのできる実用的な移動体を開発す ることである (Fig. 2). より具体的なユースケースとして「近 所のコンビニエンスストアまで買い物に行く」場合を想定する. これは患者アンケートの結果から通院以外で外出する一番の目 的は日常的な買い物であるためである [1]. さらにHOT 患者の 多くは高齢で年金生活者であることから，本研究では実用化を 見据え, 当初から可能な限り廉価で実現できるよう機構・制御 系を工夫する.

ところで人に追従し荷物を搬送する，というアイディアその ものは従来からしばしば提案され, 実機開発や試験的運用も行 われている $[2] 〜[5]$. しかしながら過去の研究の多くはレーザ レンジファインダや画像認識など高価な複数の無線のセンサを 用いており，本研究の開発目的にはそぐわない，そこで筆者ら は, そもそも患者と酸素機器がチューブで繋がれていることに 着目し, 有線により先導する患者の位置を計測することを考え た、実際, 筆者らは人や複数ロボットの軌道追従に対し, 直線 的に張った有線式のテザーの向きと長さを計測することで先導 者の軌道を安価かつロバストに計測する手法を過去に提案して おり [6], この手法を用いることとする.

テザーによる追従制御は筆者らの研究も含めいくつかの先行 研究があるが, 高価な力センサを利用していたり [7] [8], テザー のたるみにより挙動が振動的になる $[9]$ など問題があった。 また 追従制御は基本的には後述する疑似ジョイスティック制御を用 いており, 軌道追従の精度は不十分であった. さらに水平面上 のみでの移動環境を想定しており, 屋外の車道一歩道間の段差踏 破を実現する小型搬送システムは筆者らの知る限り開発されて いない.

筆者らは，現在までに基本的仕様の検討や長距離走行試験 [10], 切り下げのある歩道と車道との間の平均的な段差高さ $50[\mathrm{~mm}]$ を踏破できる車両の開発などを行った $[11]$ が, 本報告では車両 の懸架機構と能動車輪にさらに改良を加え, 法規上歩道を走行す ることになっている電動シニアカーの一般的仕様である $80[\mathrm{~mm}]$

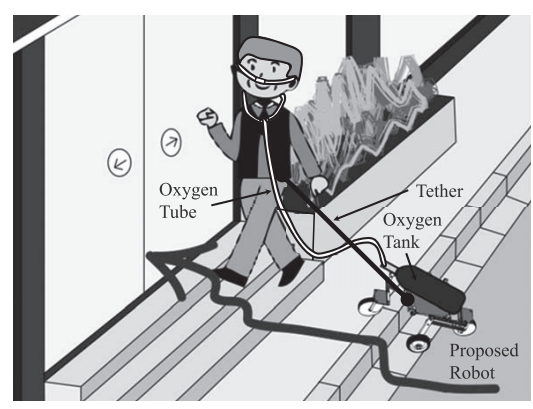

Fig. 2 Basic concept of a proposed assistive mobile robot that carries an oxygen tank
の段差を踏破できる, 小型かつ軽量の車両を開発する。また実 際に酸素ボンベを運べるよう積載スペースも考慮した設計・試作 を行う。さらに従来の追従アルゴリズムを改良し，よりテザー 長変化の少ない制御手法を提案し実装する。

\section{2. 搬送移動体の開発}

\section{1 基本設計}

二つの駆動車輪を本体左右に装備する独立駆動輪型の移動体 は進行する速さと向きを左右駆動輪の速度制御により容易に実 現でき, 最も軽量簡素かつ廉価に構成可能である。このような 移動体は通常前後方向への転倒を防止するため, 本体前後に受 動キャス夕を装備することが一般的であるが, 段差や不整地で の踏破性が低く歩道環境の走破に十分とは言い難い.

そこで本研究では高い不整地踏破性を発揮する惑星探査車両 の懸架機構に着目した。なぜなら惑星探査車両は軽量・コンパク ト・簡素な構成を満たしつつ，高い踏破性を実現するため多く の努力がなされており，その目標は本アプリケーションで目指 す移動体と共通する点が多くあるためである。本研究では特に 筆者らの開発した菱形 4 輪探査ローバー “飛燕 II 号機”をべー スとして検討する。飛燕 II 号機は能動車輪を前 1 輪, 中 2 輪, 後 1 輪の菱形に配置し, 6 輪車と同等の不整地踏破性をより少 ない 4 輪で実現することを目指している. 平行リンク機構と連 結差動機構により車重を四つの駆動輪に均等に分配することが でき, 車輪半径以上の段差を踏破するなど, 高い不整地踏破性 を実現した（Fig. 3）[12] [13].

Fig. 4 (a) に飛燕 II 号機の懸架機構を示す．飛燕 II 号機は 4 輪駆動車両であり, 前輪と中左輪, 後輪と中右輪がおのおの平 行リンク機構によりリンク中点で懸架されている.さらにこれ ら二つの平行リンク機構の間にはリンク回転角が前後で対称と なるよう連結差動機構が導入されている. 差動機構は様々な等 価機構が考えられるが図では二つのプーリにベルトをたすき掛 けにすることで便宜的に示している。これらの機構により前後 の車輪が持ち上げられると中輪は下側に押し下げられ, その結 果 4 輪にかかる車重は均等になる.

本研究ではさらなる簡素化·低価格化のため左右中輪のみ能動 車輪とし, 前後輪は一般的な首振り受動車輪としている。前輪 が受動車輪であり駆動力を生成できないことから, 段差踏破時 に中輪の駆動力によって前輪が押し上げられるよう, 前報では 平行リンクに初期オフセット角度を導入した [11]（Fig.4(b)).

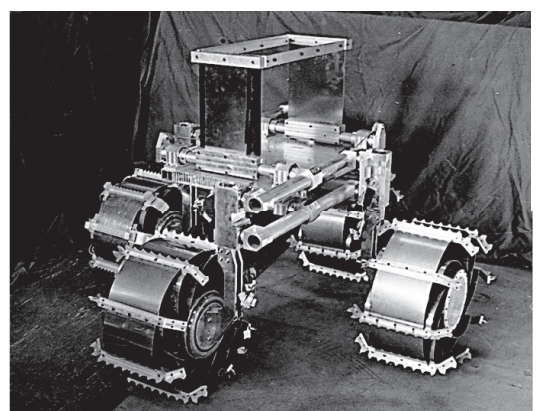

Fig. 3 Prototype model of a mars exploration rover "Hien II" 


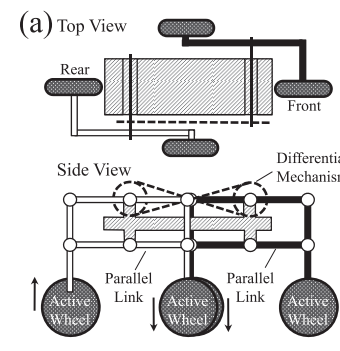

(c) Top View
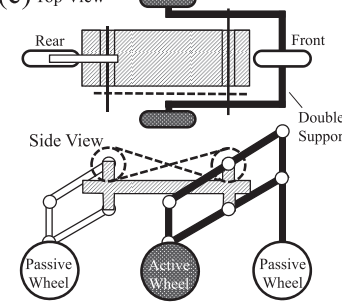

(b)

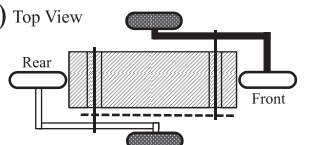

Side View
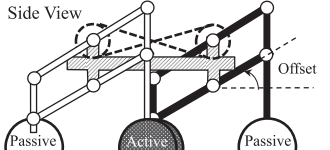

Passive

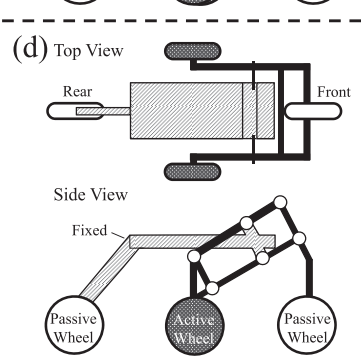

Fig. 4 Modification of the bogie link system: (a) Hien II with four active wheels, (b) introducing initial offset to the bogie links, (c) double support beam structure for the bogie links, (d) fixing the rear wheel steering axis to the body (final design)

しかしながら平行リンクおよび前後輪が片持ち構造であったた め構造的に堅牢ではなかった.

そこで Fig. 4 (c) に示すように前輪と左右中輪を懸架する両 持ち構造の平行リンク機構を考える. Fig. 4 (b) の場合と各車輪 のボディに対する相対運動はまったく同一ではないが, ほぼ同 様の動きを示し, 実際後述する動力学シミュレータでの検証に よってその段差踏破性にほとんど差がないことを確かめること ができる.

さらに機構を単純化するために後輪リンク機構および連結差 動機構について考察する．ボデイを絶対空間に固定しこれを基 準として前後輪と中輪の位置関係を考えると, 後輪も前輪と対 称に運動することが必要に思われる。しかしながら前後輪と中 輪の相対運動を中輪を基準に考えれば，後輪はボディと直接連結 されていてボディとともに傾斜した場合とほとんど変わらない， 厳密には平行リンクの運動やボディの傾斜によって重心位置が 変動するが, これらは平行リンクの支点位置や初期オフセット 角度を適切に設計することで対応できる，よって本報告では堅 牢性も増し連結差動機構を省いてさらに簡潔にできる Fig. 4 (d) の構造を提案し採用する。

\section{2 平行リンク機構の静力学解析}

本節では前輪（または中輪）の段差踏破時に必要な中輪の駆 動力 $F$ が, 平行リンクの長さや支点位置, 初期オフセット角度 に応じてどのように変化するか二次元平面問題として静力学解 析を行う.

記号を Fig. 5 のように定める. $L_{i}, G_{j}$ はそれぞれリンク長, 重力であり， $\phi_{1,2}$ は初期角度オフセットとする. 中輪は常に前 後輪のホイールベース $W$ の半分の位置にあるとし, 車輪径は 同一とする， $\alpha, \zeta$ はイールベースや車輪径, 段差高さによっ て幾何学的に定まる角度である．前輪踏破時に段差から受ける 反力はもっとも厳しい条件である水平方向と仮定する．各リン

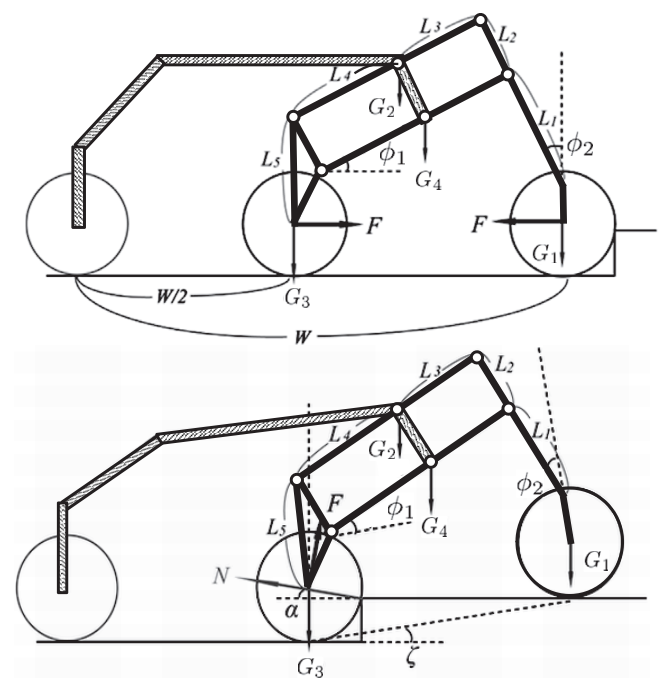

Fig. 5 Static force analysis: front wheel negotiating (top), middle wheel negotiating (bottom)

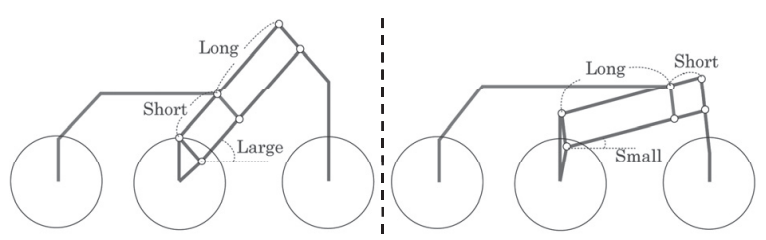

Fig. 6 Results of the static force analysis: suitable for the front wheel negotiation (left), for the middle wheel negotiation (right)

クごとにカとモーメントの釣り合いの式を立て，それらを解く ことで前輪踏破の条件式 (1), 中輪踏破の条件式（2）を得る，

$$
\begin{gathered}
F>\frac{G_{1}+\frac{L_{4}}{L_{3}+L_{4}}\left(G_{2}+G_{4}\right)}{\tan \phi_{1}} \\
F>G_{3} \cos \alpha+\frac{\left(G_{2}+G_{4}\right) L_{3}}{L_{3}+L_{4}} \frac{\cos \left(\phi_{1}+\zeta\right)}{\cos \left(\phi_{1}+\alpha+\zeta\right)}
\end{gathered}
$$

式（1）（2）より $L_{3} / L_{4}, \phi_{1}$ が大きければ前輪踏破時に必要 な駆動力 $F$ が小さくなるがその一方で, 中輪踏破時に必要な駆 動力が大きくなる。 これを定性的に図示すると Fig. 6 になる. よってリンクパラメータの調整による前輪と中輪の踏破性向上 はトレードオフの関係にあることが示唆される.

2.3 動力学シミュレータによるリンクパラメータの最適化 本節では動力学シミュレータ "Open Dynamics Engine (ODE)”[14] を用いて数值的に検討する. まず Fig. 4 (b)(c) に 示す懸架機構で段差踏破実験を行い, Fig. 4(d) との比較を行っ たが, 明確な性能差は見られなかった。よってより単純な機構 である Fig. 4(d) を採用する. 次にこの形態においてリンクパ ラメータ $L_{3} / L_{4}$ と $\phi_{1}$ を数值的に最適化する. 最適化のための 評価基準は（1）各車輪が段差踏破する際の必要中輪推進力 $F$ の最大值の均一化, (2) 踏破可能段差高さの最大化（車輪半径 $r=0.2 W$ の $80 \%$ 以上) である. Fig. 7 はシミュレーション に用いた車両モデルである。大きさや質量などは従来の試作と 3DCAD モデルに基づき現実的な值を設定している。 な抢本体 

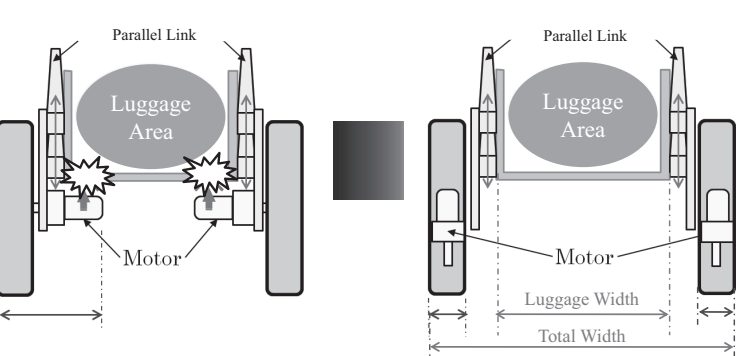

Fig. 7 Simulation model for the dynamics simulator
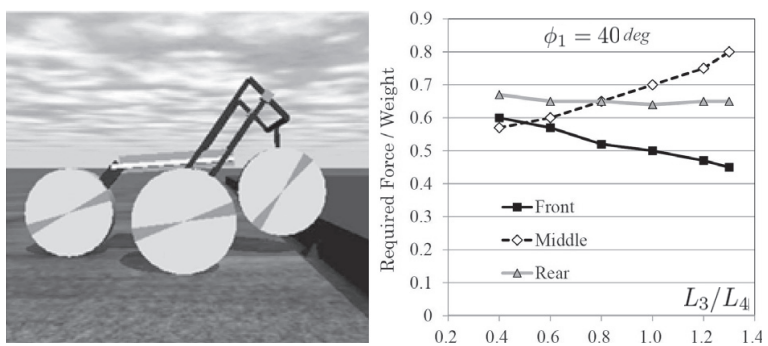

Fig. 8 An example of ODE simulation (left) and required force (right)

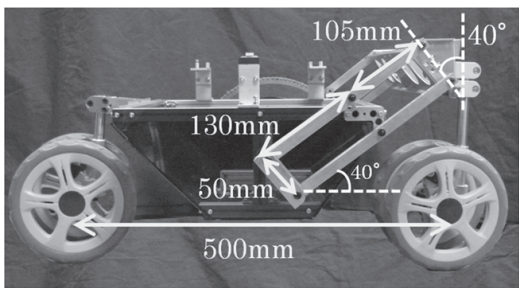

Fig. 9 Hardware implementation with the optimized link parameters (the middle wheel is not attached)

総質量 $M$ はペイロードである酸素ボンベやその付属品質量も 含んでいる.

車輪と走行面の摩擦係数を 0.7 と設定し, 中輪を速度制御 することによって $0.8[\mathrm{~m} / \mathrm{s}]$ の速さで段差に進入する際の必要 中輪推進力 $F$ の最大值を計測した。 $(0.2 \leq L 3 / L 4 \leq 1.6)$, $\left(10 \leq \phi_{1} \leq 50\right)[\mathrm{deg}]$ の範囲で網羅的にシミュレーションを 行った. 一例として Fig. 8 左にシミュレーションの様子を, 右 に $\phi_{1}=40[\mathrm{deg}]$ のときの正規化推進力 $F / M g$ (ただし $g$ は重 力加速度）と $L_{3} / L_{4}$ の関係を示す. 静力学解析の結果式 (1)

(2) で予想されたとおり， $L_{3} / L_{4}$ が大きくなると前輪踏破は容 易になるが反対に中輪踏破が困難になる様子が分かる.

踏破可能な段差を最大化し, かつ各車輪が乗り越える際の $F$ の最大值の変動が $20 \%$ 以内に収まるリンクパラメータを求めた 結果, $L_{3} / L_{4}=0.8, \phi_{1}=40[\mathrm{deg}]$ の值を得た. このとき, 踏 破可能な最大段差高さは $0.9 r$ であった，実際に構成したボギー リンク機構を Fig. 9 に示す。取り回しの容易さや積載性を考慮 して前後輪のホイールベースを $W=500[\mathrm{~mm}]$ と設定したた め, 設計上の踏破可能最大段差高さは $90[\mathrm{~mm}]$ である.

\section{4 大径偏平能動車輪}

開発する車両は酸素機器を搬送するための積載スペースを十分 に取ることが望ましい. 一方, 歩道を走ることや取り回しやすさ を考慮すれば，車幅はできるだけ小さい方が望ましい．Fig.10

Fig. 10 Problem of the conventional actuator arrangement (left) and proposed arrangement (right)

(a)
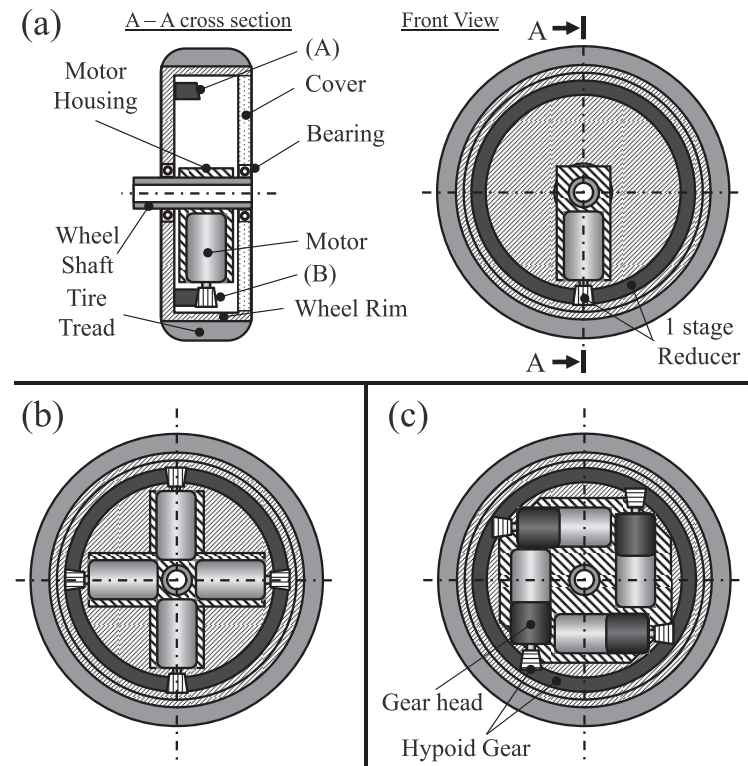

Fig. 11 Proposed low-profile in-wheel motor

左にアクチュエータ出力軸を車輪と同軸に配置する通常の駆動 系を示す，最も単純な構成であるが，本論文で検討している懸架 機構や他のサスペンション機構を設けると, アクチュエータが 突出した形であるため荷物を搬送する車両本体と干渉してしま い, 上方への可動範囲が制限される。 もし能動車輪内部にアク チュエータを配置することができれば懸架機構に対し大きな可 動範囲を確保することができる。ささらに車幅全体に占める荷台 の幅を最大化することを考えると能動車輪は薄く偏平であるこ とが望ましい，モー夕軸と車軸を同軸にした通常のインホイー ルモータでは車輪幅が大きく，また廉価で入手可能な市販品は 数 $\mathrm{kg}$ の質量であった. そこで Fig. 10 右に示す新たなアクチュ エータ配置を提案する.

Fig. 11 (a) に提案する偏平能動車輪の基本構成を示す。車軸 とモータハウジング, モータは一体であり相対運動しない. よっ てモータへの配線は中空車軸を通して外部電源に接続できる. 部材（A）とホイールリムも一体である（Fig.11(a)）。（左断面 図に記したカバーとベアリングは図を見やすくするため正面図 には図示していない）車軸とホイールリム部材はベアリングを 介して保持されていることから，相対的に回転可能である。そ して部材（A）（B）は単段減速機構であり, モータの回転を車 輪の回転駆動へと変換している。単段の減速機構としては（1） 

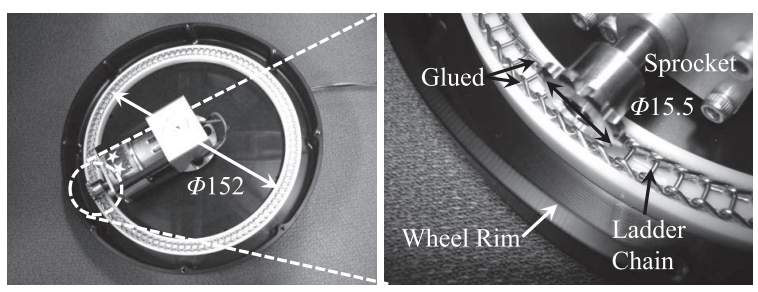

Fig. 12 Developed low-profile in-wheel motor

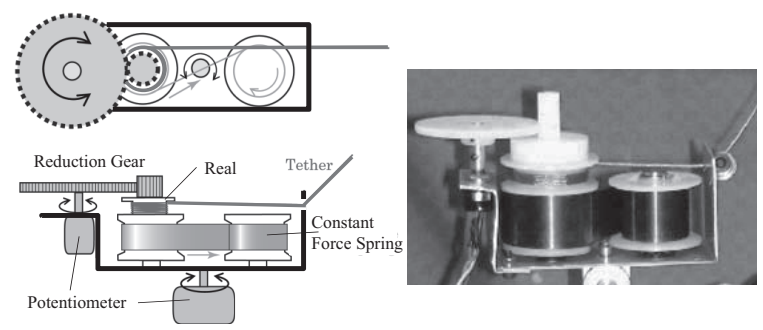

Fig. 13 Tether mechanism to measure the tether length and direction

傘歯車, (2) 摩擦車, (3) クラウンギア, (4) ピン歯車とスプ ロケット，（5）ラダーチェーンとスプロケットなどの様々な方 式が考えられる。

提案する構成では車輪の大きな径を利用しているため単段で も大きな減速比を取ることができる，単段であることから高い 効率が期待できる。 また軸は車軸とモー夕軸の二つであり, 部 品点数が少なくてすむためその結果信頼性が向上するとともに 製造コストを抑えることができる．特に部材（A）とホイール リムを射出成型により一体で作れば，量産化も容易である。さ らに車軸部分のみシールすれば良いことから, 防塵防水設計が 容易である.

本機構の発展型として, より高い出力を目指して放射状にモー 夕を配置することも考えられる（Fig. $11(\mathrm{~b})$ )。 また仮に目標と する減速比が前述の単段減速では得られない場合はギアヘッド を装着することも考えられる。この場合, 総部品点数は増加し モータ全長も長くなる．しかしギアヘッドの部品点数増加はメー 力側で多くの場合信頼性が確保されていて低価格化もされてい ることから，導入による信頼性・コスト面で影響は少ないと思 われる。 また Fig. 11 (c) に示す配置をし，ハイポイドギアによ り車輪駆動すればモー夕全長が長くなる場合でも対応できる.

試作した車輪を Fig. 12 に示す。実際の試作においては単段 の減速機構部材 (A) にラダーチェーンを, 部材 (B) にスプロ ケットを選択した。これは製作コストと加工の容易さを優先し たためである．溝を掘ったリング状部材にラダーチェーンを嵌 めこみ，接着している．またアクチュエータには定格約 $17[\mathrm{~W}]$ のギアヘッド付きDCアクチュエータ（夕ミヤ製：380K20）を 用いた。 ギアヘッドの減速比は $1 / 20$, チェーンとスプロケット による減速比は $1 / 10.4$ である.

\section{5 テザー機構}

先導者の相対位置は Fig. 13 に示すテザー機構を用いて計測 する. 将来的には酸素チューブと兼用することも十分考えられ るが, ここでは既製品を利用できるワイヤを選択した。ワイヤ

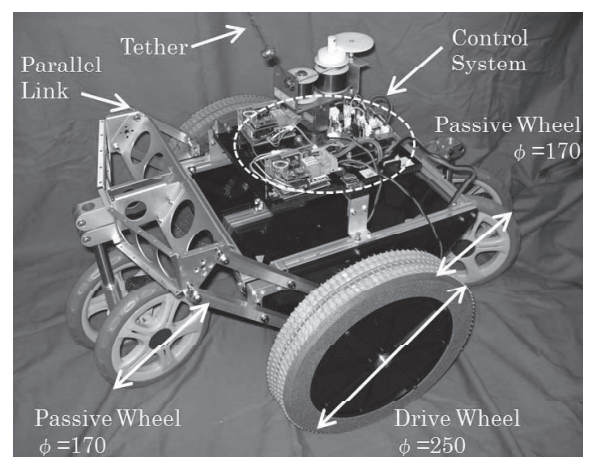

Fig. 14 Overview of the prototype

Table 1 Specification of the prototype

\begin{tabular}{|c|l|}
\hline Dimension $[\mathrm{W} \times \mathrm{L} \times \mathrm{H}]$ & $460 \times 670 \times 420[\mathrm{~mm}]$ \\
\hline Mass & $8.8[\mathrm{~kg}]($ with a tank \& batteries $)$ \\
\hline Wheel diameter & $170[\mathrm{~mm}], 250[\mathrm{~mm}]$ \\
\hline Maximum velocity & $1.0[\mathrm{~m} / \mathrm{s}]$ \\
\hline Battery & $\begin{array}{l}\text { LEAD-ACID: } 12 \mathrm{~V}-2.0 \mathrm{Ah} \times 2 \\
(\mathrm{NP} 2-12, \text { GS Yuasa })\end{array}$ \\
\hline Actuator & $20[\mathrm{~W}] \times 2:$ Tamiya $380 \mathrm{~K} 20$ \\
\hline Reduction ratio & 208 \\
\hline Direction angle sensor & Potentiometer \\
\hline Winding angle sensor & \\
\hline CPU & SH7047F CLK $/ 44.2[\mathrm{MHz}]($ Hitachi) \\
\hline Motor Driver & TITech Robot Driver Ver.2 \\
\hline
\end{tabular}

の長さに依らず一定張力を生成できる定荷重バネ（サンコース プリング製：コンストン NWS-0.25-1）を用い, ワイヤの繰り 出し量と向きをポテンショメータによって計測する，定荷重バ ネはワイヤが弛まないよう張るだけの張力を与えればよいので 最も小さい張力 $2.45[\mathrm{~N}]$ の製品を選択した。これはワイヤ端部 を腰に付けて㐮引した場合，ほとんど知覚することのできない 小さな值であることから, 患者の歩行の妨げにはならないと考 えられる。本機構は無線式のレーザレンジファインダやステレ オビジョンなどに比して格段に低価格で堅牢に構成できる.

\section{6 システム統合}

試作機の概観を Fig. 14 に示す。今までの解析ではすべての 車輪径を同じとしてリンク機構を検討してきたが, 実機では酸 素ボンベと付属機器のための積載スペースを確保するため, 前 後輪はより小さな車輪径とした。この場合であっても踏破可能 な最大段差高さにはほとんど影響を与えない.なぜなら, 駆動 力は中輪のみで生成され，また前後輪の踏破は主に平行リンク 機構の効果によって達成されているからである。このことは動 力学シミュレータにおいて事前に検証した。駆動輪である中輪 は TITech Robot Driver Ver.2 によってタコジェネレータなし で速度制御されている。テザーの向きや長さはポテンショメー 夕によって計測し，アナログ電圧をマイコン（ハイボット社製: TITech SH2 Tiny Controller) によって読み取り，モータドラ イバへの指令值を生成している. Table 1 に開発した移動体の 諸元を示す。

\section{3. テザーによる追従制御}

筆者らはテザーによる i）ロボット間の連結，ii）ロボットと 

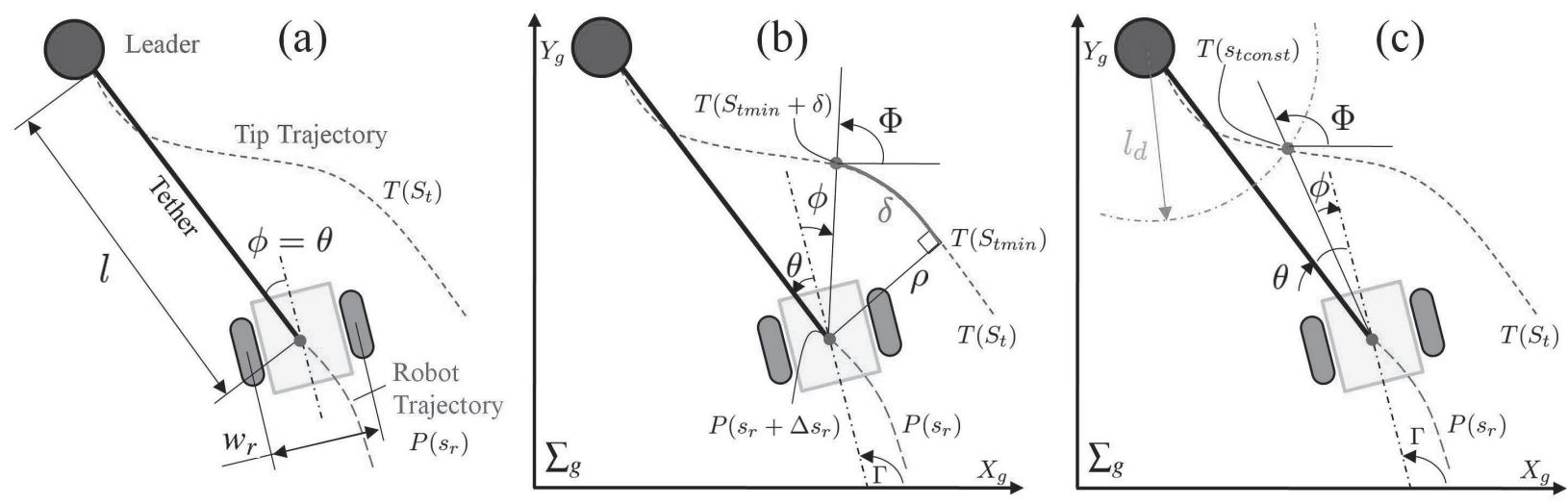

Fig. 15 Algorithm for the leader following: (a) pseudo-joystick control, (b) follow-theleader algorithm, (c) modified follow-the-leader algorithm

環境との連結, iii) ロボットと人間との連結, iv) 複数経路を 介した連結，v）電源伝送，vi）情報通信，vii）自動操舵指令生 成などの機能を有する包括的な連結手段の概念を「ハイパー・ テザー」と名付け [15] 研究を進めてきた。そのなかでも特に先 導者に追従するための操舵信号の自動生成については, 単に現 在の先導者の位置に向かって進むのではなく, 先導者の通った 位置軌道をいったん慣性座標系で記述し，その軌道上に漸近す るよう速度指令を生成することで, より高い精度で軌道追従が できることを示してきた $[6]$. 本章では従来研究でしばしば用い られている疑似ジョイスティック操舵制御，筆者らの提案した 先導体追尾制御について概要を述べるとともに, テザー長の変 動がより少なくなる新たなアルゴリズムの提案を行う.

\section{1 疑似ジョイスティック操舵制御}

テザーの向きと長さをロボットの目標速度ベクトルとみなし て追従を行う手法はもっとも直観的かつ直接的な実装方法であ る（Fig. $15(\mathrm{a})$ ). ロボットの並進速度 $V_{r}$ と角速度 $\Omega_{r}$ は次式 で得られる。

$$
\begin{gathered}
V_{r}=-K_{p}\left(l_{m}-l_{d}\right) \cos \phi, \\
\Omega_{r}=-\frac{2 V_{r}}{w_{r}} \sin \phi, \\
\phi=\theta
\end{gathered}
$$

ここで $l_{m}, l_{d}$ はそれぞれ実測テザー長, 目標テザー長であり， $K_{p}$ は速度ゲイン, $w_{r}$ はロボットの車幅である. 目標移動方向 である $\phi$ はロボットの胴体座標系から見た相対角度 $\theta$ である ため、ロボットはテザーの引かれた方向に移動する. 左右の駆 動輪に与えられる角速度指令 $\omega_{L}, \omega_{R}$ は次式で求められる.

$$
\mathbf{V}=\mathbf{A}^{-1} \mathbf{q}
$$

ここで $\mathbf{V}=\left[\begin{array}{ll}\omega_{L} & \omega_{R}\end{array}\right]^{T}, \mathbf{q}=\left[\begin{array}{ll}V_{r} & \Omega_{r}\end{array}\right]$ であり, 半径 $r$ の車輪 の回転角速度をロボット本体の速度べクトルに変換する行列 $\mathbf{A}$ は次式となる。

$$
\mathbf{A}=\left[\begin{array}{cc}
r / 2 & r / 2 \\
-2 r / w_{r} & 2 r / w_{r}
\end{array}\right]
$$

\section{2 先導体追尾制御}

テザー先端の移動軌跡の履歴を一定期間蓄えることができれ ば，追従ロボットから見た先導者の位置軌道への追従精度を向 上させることができる，慣性座標系 $\sum_{g}$ から見たロボット自 身の位置と姿勢を記録しておけば，同じ慣性座標系から見たテ ザー先端の移動軌跡の履歴も得ることができる。ここでテザー 先端，ロボットの軌道をそれぞれ $\mathbf{T}\left(s_{t}\right), \mathbf{P}\left(s_{r}\right)$ とし, $s_{t}, s_{r}$ をそれぞれの軌道の媒介変数とする（Fig. 15 (b)）。目標移動方 向 $\phi$ は次のアルゴリズムによって得られる.

Step 1: デッドレコニング法によりロボットの位置を推定する. i）時間 $t$ に扔ける並進速度と角速度を推定する.

$$
\mathbf{q}=\mathbf{A V}
$$

ii）慣性座標系 $\sum_{g}$ に対するロボットの向き $\Gamma$ を導出する.

$$
\Gamma(t+\Delta t)=\Gamma(t)+\Omega_{r}(t) \Delta t
$$

iii）ロボットの移動距離 $\Delta s_{r}$ を導出する.

$$
\Delta s_{r}=V_{r} \Delta t
$$

iv）ロボット位置 $\mathbf{P}\left(s_{r}\right)$ を更新する.

$$
\mathbf{P}\left(s_{r}+\Delta s_{r}\right)=\mathbf{P}\left(s_{r}\right)+\mathbf{E}^{k \Theta}\left[\begin{array}{c}
\Delta s_{r} \\
0
\end{array}\right]
$$

ここで $\Theta=\Gamma+\theta$ は $\sum_{g}$ から見たテザーの方向で次式を満 たす。

$$
\mathbf{E}^{k \Theta}=\left[\begin{array}{cc}
\cos \Theta & -\sin \Theta \\
\sin \Theta & \cos \Theta
\end{array}\right] .
$$

Step 2: テザー先端位置 $\mathbf{T}\left(s_{t}+\Delta s_{t}\right)$ を導出する.

$$
\mathbf{T}\left(s_{t}+\Delta s_{t}\right)=\mathbf{P}\left(s_{r}+\Delta s_{r}\right)+\mathbf{E}^{k \Theta}\left[\begin{array}{c}
l_{m} \\
0
\end{array}\right]
$$

Step 3: テザー先端部の移動距離を導出する.

$$
\Delta s_{t}=\left\|\mathbf{T}\left(s_{t}+\Delta s_{t}\right)-\mathbf{T}\left(s_{t}\right)\right\|
$$


Step 4: 目標移動方向 $\phi$ を導出する.

ロボット位置 $\mathbf{P}\left(s_{r}+\Delta s_{r}\right)$ との最短距離 $\rho$ に位置するテザー先 端軌道上の点 $s_{t \text { min }}$ を探索し, 距離 $\delta$ 進んだ位置 $\mathbf{T}\left(s_{t m i n}+\delta\right)$ までにロボット位置がテザー軌道に漸近的に収束するような操 舵指令を導出する. いくつかの方法が考えられるが, 本論文で はロボット目標移動方向 $\phi$ を次式で求める.

$$
\phi=\Phi-\Gamma
$$

ここで $\Phi$ は慣性座標系 $\sum_{g}$ から見たロボット目標移動方向で ある.この目標移動方向と式 (3)，（4），（6）から目標車輪速度 を求めることができる. 本手法は疑似ジョイステイック操舵制 御に比してより高い軌道追従制御が可能であり, 実際 2 台のク ローラロボットの追従制御実験によってすでに検証している [6].

\section{3 定距離先導体追尾制御}

前節の先導体追尾制御では軌道追従性の向上を最優先とし, 先導者とロボットの間隔は式（3）によって結果的に保たれてい るものの, 優先順位は低かった. しかしながら本アプリケーショ ンでは先導者 (患者) とロボットは酸素チューブによっても物 理的に連結されており，チューブ長さにも限界があることから， 先導者とロボットの距離を一定に保つことは非常に重要である. またODEによるシミュレーションの結果, 先導体追尾制御で は先導者に急速な速度変動があると追尾が不安定になる現象が 観測された。これは前節 Step 4 において先導者速度と無関係で 経験的に調整される $\delta$ という距離を設定しているためであると 推測される.

この問題を解決するため, 目標移動方向 $\phi$ の導出を改善する ことで, 明示的に先導者一ロボット間の距離を一定にする手法を 「定距離先導体追尾制御」と名付け提案する。 これは目標移動方 向を $\mathbf{T}\left(s_{t m i n}+\delta\right)$ から求めるのではなく, 代わりに現在の先 導者位置を中心とし, 目標テザー長 $l_{d}$ を半径とする円と $\mathbf{T}\left(s_{t}\right)$ との交点 $\mathbf{T}\left(s_{\text {tconst }}\right)$ から求める方法である（Fig. $15(\mathrm{c})$ ). さら に式（3），(4) の代わりに $K_{a}, K_{b}$ を制御ゲインとした次式を 用いる。

$$
\begin{gathered}
V_{r}=-K_{p}\left(l_{m}-l_{d}\right)\left(1-K_{a}|\phi|\right), \\
\Omega_{r}=-K_{b} \phi
\end{gathered}
$$

式（16）では目標移動方向 $\phi$ が大きくなるにつれロボット並進 速度 $V_{r}$ が小さくなる効果がある。これは先導者が急激に向き を変えた場合に有効である，また $\Omega_{r}$ に関しては式 $(3)$ では $V_{r}$ に比例しており， $V_{r}=0$ のとき，すなわちテザーの伸びが ゼロの場合はロボットの向きは変わらない. しかしながら本ア プリケーションでは酸素チューブが絡まることを防ぐため, 口 ボット本体の向きはテザー長にかかわらず常に先導者向きであ ると都合がよいと考えられる。

提案する手法の有効性を ODE を用いて検証した。先導者は Fig. 16 に示す黒点線のコの字型の経路を一定速度 $0.5[\mathrm{~m} / \mathrm{s}]$ で 歩くものとする. $l_{d}$ は歩行時に脚が移動体に干渉せず, なおか つ先導者に近い值として $0.8[\mathrm{~m}]$ と設定した. 各制御法とも追 従性は式（3），(16），（17）に含まれるゲインに大きく依存す る.おのおのの制御法に対し, なるべく軌道追従誤差が小さく,

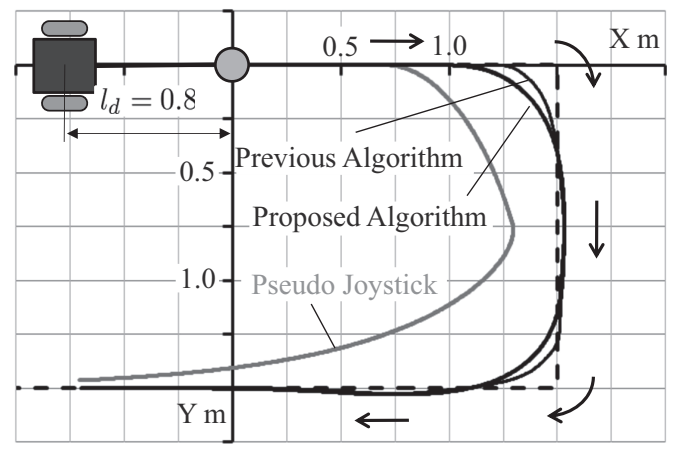

Fig. 16 Trajectory following simulation using three different algorithms: (a) pseudo-joystick control, (b) follow-theleader control, (c) modified follow-the-leader control

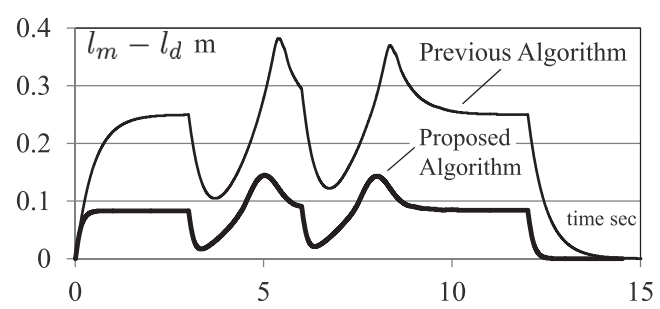

Fig. 17 Time course of the tether length deviation

かつ発振が起こらないゲインを十分な時間をかけて試行錯誤的 に探索し，設定した。

検証した三つの制御法では先導体追尾制御が最も軌道追従誤 差が少なく, 次いで提案する定距離先導体追尾制御がわずかに 劣っていた．疑似ジョイステイック操舵制御は大きな誤差があ ることが分かる。一方で追従中のテザー長の変化を計測すると

Fig. 17 に示すとおり, 定距離先導体追尾制御は先導体追尾制御 の半分程度のテザー長変化に押えられていることが分かり, 本 アプリケーションに適した制御と考えられる.さらに ODE 上 でキーボード入力により先導者の移動速度を様々に変化させて 追従の挙動を検証したところ, 提案する定距離先導体追尾制御 は従来の制御法に比して発振が少なく滑らかに追従する様子が 確認できた.

\section{4. 実験}

\section{1 段差踏破実験}

試作した実験機の段差踏破性能を確かめるため実験を行った. 車両の推進速度を $0.8[\mathrm{~m} / \mathrm{s}]$ とし， $5[\mathrm{~mm}]$ ずつ段差を高くするこ とで踏破可能な最大段差高さ $80[\mathrm{~mm}]$ を得た (Fig. 18). この值 は動力学シミュレーションの予測值より $10[\mathrm{~mm}]$ 低い值である が, 通常, 歩道一車道間の高さ $90[\mathrm{~mm}]$ の縁石には角に $15[\mathrm{~mm}]$ 程度の $\mathrm{R}$ があり, 段差とタイヤの接地点の高さは $80[\mathrm{~mm}]$ 程度 となることから, 問題なく踏破できるものと考えられる. 実際, 屋外の縁石上で踏破実験を行ったところ踏破が可能であること が確かめられた（Fig. 19）。

最大段差高さと車輪半径の比を求めると前後輪では 0.94 , 中 輪では 0.64 であった. 従来の差動 2 輪駆動型ロボット（例えば Mobile Robotics 社製: Pioneer-3DX) ではその值はおよそ 0.3 程度であり，本報で提案した懸架機構が段差踏破性を大きく向 
上していることが分かる. Fig. 20 は $60[\mathrm{~mm}]$ の段差踏破時に 必要な中輪卜ルクについて動力学シミュレーションで得られる 值と実験值を比較している。シミュレーションは試作機に合わ せてシミュレータ内の機構モデルを変更した上で計測した。実 験值はアクチュエータ電流計測值にトルク定数 $2.75[\mathrm{mNm} / \mathrm{A}]$, 減速比 208 を乗じることで算出した. 実験值は電流值からの推 定であるので減速機の効率など䛊差を含んでいるが，各輪が段 差踏破する際のピーク值が扮扮よそ同じ值を取っていることが 分かる. よって設計した平行リンク機構が各車輪に適切に車体 重量を分散させて段差踏破を実現していることが示唆される。

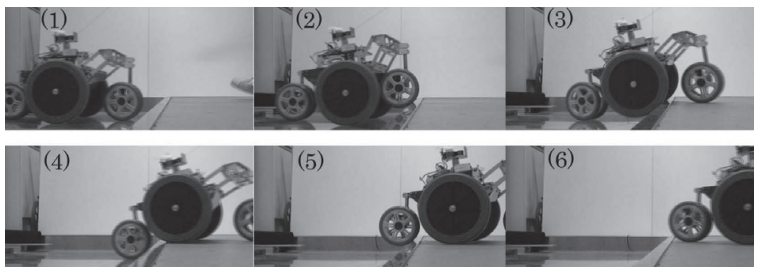

Fig. 18 Step climbing experiment: height of the step $80[\mathrm{~mm}]$
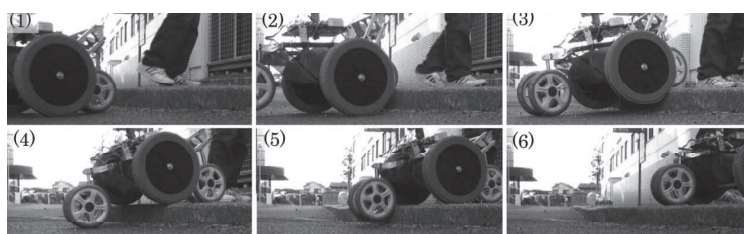

Fig. 19 Step climbing experiment: height of the curb $90[\mathrm{~mm}]$

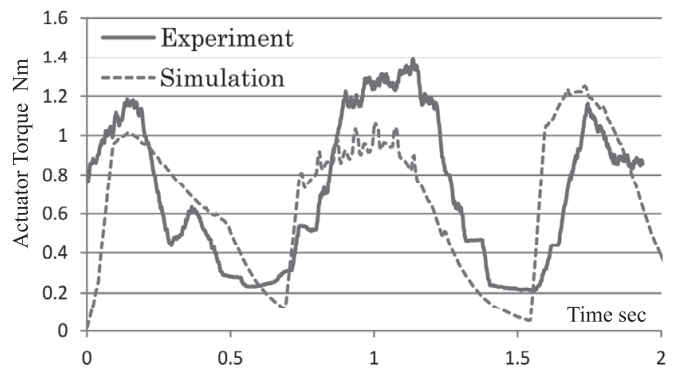

Fig. 20 Driving torque comparison between simulation and experiment negotiating $60[\mathrm{~mm}]$ height step

\section{2 屋外追従実験}

屋外での追従実験の様子を Fig. 21 に示す．先導者は車止め を回避するため Fig. 21 右のような経路を通っている.テザー の先端は先導者の腰に付けられているため, 先導者は両手を使 うことができる。これは杖をつく，傘を差す，鞄を持つなどの ことを考えると大きな利点であると考えている。移動ロボット は幅 $1.0[\mathrm{~m}]$, 半径 $0.5[\mathrm{~m}]$ の狭隘な通路を先導者に追従して通 過することができた

最後に実際のユースケースを想定した追従実験を行った，東 京工業大学大岡山キャンパス石川台 1 号館 5 階を出発点とし, およそ $300[\mathrm{~m}]$ 離れたキャンパス内のコンビニエンスストアを 終点とする経路である。経路の途中にはエレベータ, 自動ドア, 車椅子用スロープ，マンホール，側溝のグレーチング, $50[\mathrm{~mm}]$ のコンクリート段差などがあったが，いずれも問題なく通過す ることができ，目的地まで到着することができた。

\section{5. ま と め}

本論文では在宅酸素療法患者の外出を支援するため, 酸素機 器を搬送することのできる追従型移動体の開発を行った。特に 差動 2 輪駆動型の車両の段差踏破性を高めるため, 両持ち構造 で堅牢な平行リンク機構を新たに提案しそれを最適化すること で歩道一車道間の高さ $80[\mathrm{~mm}]$ の縁石を破踏できる移動体を実 現した。また実際に酸素機器を搭載できるよう大径偏平能動車 輪を用いて十分な荷物スペースを考慮した試作機を開発した。 また先導者の軌道に追従しつつテザー長変化の少ない制御アル ゴリズムを提案し，その有効性を確認した。最後に実験機によ り段差踏破実験, 屋外での追従実験を行い, 各機能の実現を確 認した.

現在までのところ筆者らは車両性能の向上に注力して開発を 行っている。しかしながら真に役に立つ移動ロボットとなるた めには，実歩道環境での様々な段差に対する踏破試験や，実際 の在宅酸素療法患者からのフィードバックが必要不可欠である. 実際の想定ユーザからの使用感評価に基づき，求められる大き さ・質量・稼働時間などを再検討する予定である。 また安全面 でのセンサ類やフェールセーフ設計など実用的な対策も施して いく予定である。

謝 辞 本研究は東京工業大学ベンチャー・ビジネス・ラボ

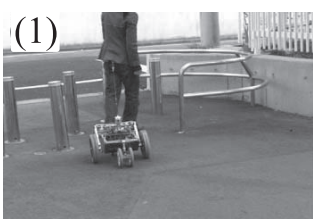

(5)

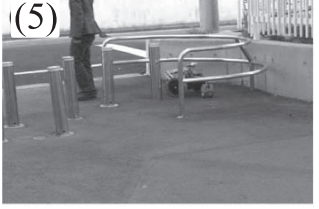

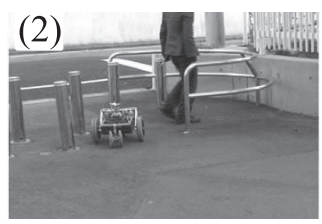

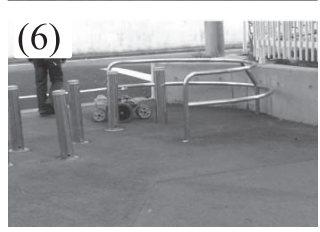

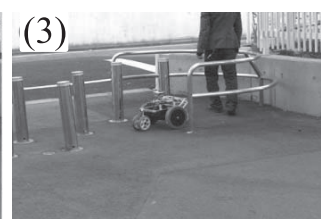
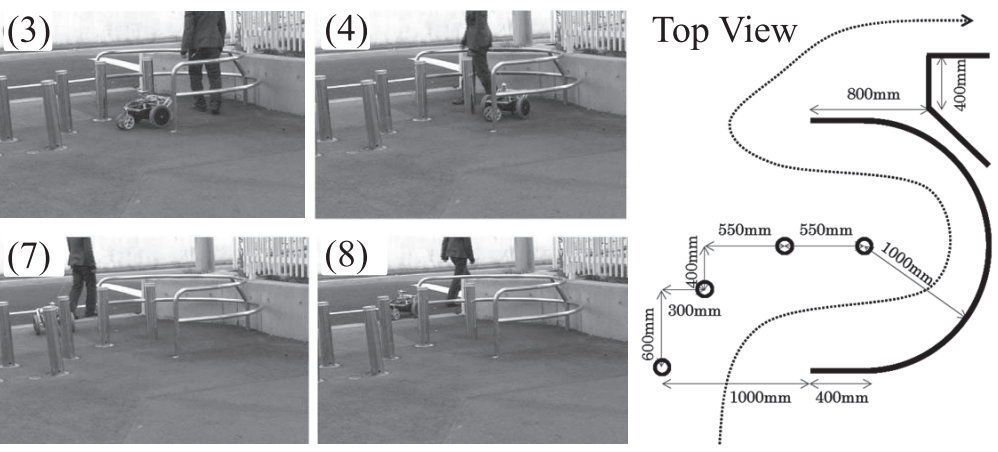

Fig. 21 An experiment passing through bollards in outdoor environment at $2.0[\mathrm{~s}]$ interval capture (left), top view of the path (right) 
ラトリー平成 20 年度研究プロジェクトの支援を受けて行われ ました。関係各位に深く感謝致します。

\section{参 考 文 献}

[1] 日本呼吸器学会肺生理専門委員会在宅呼吸ケア白書ワーキンググルー プ: 在宅呼吸ケア白書 2010. (社) 日本呼吸器学会, 2010.

[2] 岡本球夫, 後藤孝周, 姉崎隆, 足達勇治, 杉ノ内剛彦: “人追従荷物搬 送ロボットの開発一第 2 報: 技術内容—”, 第 23 回日本ロボット学 会学術講演会予稿集 CD-ROM, 1I22, 2005.

[3] 空港内搬送案内ロボット：RoboPorter（ロボポーター）, http:// robotics.ksrp.or.jp/robotforum/pdf/topics/ 2008-02-18RoboPorter_v1.pdf

[4] 松日楽信人, 小川秀樹, 吉見卓 : “人と共存する生活支援ロボット”, 東芝レビュー, vol.60, no.7, pp.112-115, 2005.

[ 5 ] トヨタ自動車パーソナルモビリティMobiro, http://www.toyota.co. jp/jpn/tech/partner_robot/family.html

[6] 福島 E. 文彦, 広瀬茂男, 亀川哲志: “ハイパー・テザーの研究その 2 テザーで連結される複数ロボットの先導体追尾制御”，第 16 回日本 ロボット学会学術講演会予稿集, pp.109-110, 1998.

[ 7 ] 安藤毅, 椛沢光隆, 近野敦, 稲葉雅幸, 井上博允: “引き綱型インタ フェースによる自立型 4 脚移動ロボットの誘導”, ロボティクス・メ カトロニクス講演会'97 講演論文集, vol.A, pp.283-286, 1997.

[8] 山田貴則, 大矢晃久, 油田信一: “人間の紐操作による移動ロボット の誘導”, 第 21 回日本ロボット学会学術講演会予稿集 CD-ROM,
3H23, 2003.

[ 9 ] 寺島亮, 石引力, 板井志郎, 三輪敬之: “紐の冗長性を活用した荷物 運搬支援モービルに関する研究—実用性向上のための紐誘導法の拡 張—”, SICE SI 部門学術講演会予稿集, pp.1102-1103, 2006.

[10] M. Iribe, H. Matsuda, H. Aizawa, G. Endo and T. Takubo: "Study on a Practical Robotic Follower to Support Daily LifeMobile Robot Development for Home Oxygen Therapy Patients with the Hyper Tether-," Journal of Robotics and Mechatronics, vol.23, no.2, pp.316-323, 2011.

[11] G. Endo et al.: "Study on a Practical Robotic Follower to Support Daily Life-Development of a Mobile Robot with "HyperTether" for Home Oxygen Therapy Patients-," International Symposium on System Integration (SI International), P01, 2009.

[12] S. Hirose, N. Ootsukasa, T. Shirasu, H. Kuwahara and K. Yoneda: "Fundamental Considerations for the Design of a Planetary Rover," Int. Conf. on Robotics and Automation, pp.1939-1944, 1995.

[13] 広瀬茂男, 古橋幸人, 大司成俊：“4 輪惑星探査ローバー飛燕 II 号機 の開発”, 第 14 回日本ロボット学会学術講演会予稿集, pp.251-252, 1996.

[14] Open Dynamics Engine, http://www.ode.org/

[15] 福島 E. 文彦, 広瀬茂男：“ハイパー・テザーの提案”, 第 15 回日本 ロボット学会学術講演会予稿集, pp.453-454, 1997.

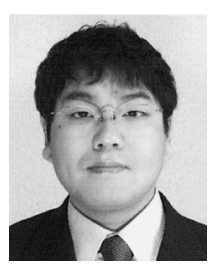

\section{遠藤 玄 (Gen Endo)}

2000 年東京工業大学機械物理工学専攻博士課程修 了. 2000 年ソニー (株) 入社. 2002 年〜 2006 年 (株) ATR 脳情報研究所客員研究員. 2007 年東京 工業大学理工学研究科特任助教を経て, 2008 年同 大学機械宇宙システム専攻助教. 追従型福祉車両, ヘビ型移動ロボット, 脚一車輪型移動ロボット, 軽 作業用マニピュレータの研究開発に従事. 日本ロボット学会第 16 回 論文賞受賞. 博士 (工学).

(日本ロボット学会正会員)

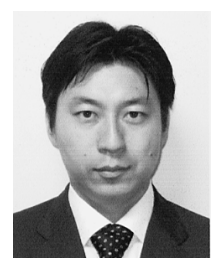

福島 E. 文彦（Edwardo F. Fukushima） 1993 年東京工業大学機械物理工学専攻修士課程修 了. 1994 年 8 月から東京工業大学工学部助手, 2006 年 11 月より同大学助教授 (現准教授), 現在に至 る。移動ロボットの機構, センサ, 駆動や制御系一 般, 人道的地雷探査システム等の研究に従事. 博士 (工学).

（日本ロボット学会正会員）

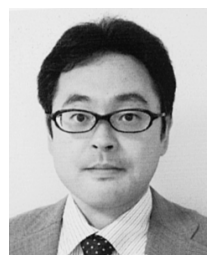

\section{入部正継 (Masatsugu Iribe)}

1993 年大阪府立大学大学院工学研究科博士前期課 程修了. 同年ソニー (株) 入社. 2007 年神戸大学 大学院自然科学研究科博士後期課程修了. 同年大阪 電気通信大学講師. 2012 年同大学準教授, 現在に 至る。ロボティクス, メカトロニクスに関する研究 に従事. 博士 (工学)。（日本ロボット学会正会員）

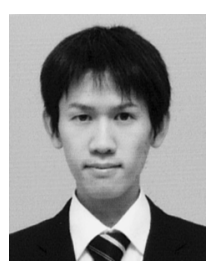

\section{谷篤 (Atsushi Tani)}

2010 年東京工業大学機械宇宙システム専攻修士課 程修了．在宅酸素療法患者のための福祉機器, 追従 型車両の研究開発に従事.

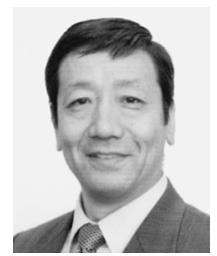

広瀬茂男 (Shigeo Hirose)

1976 年東京工業大学制御工学専攻博士課程修了 (工 学博士). 同大学助手, 助教授を経て 1992 年東京工 業大学機械物理工学科 (2000 年以降機械宇宙システ ム専攻) 教授.ロボット創造学の研究に従事. Pioneer in Robotics and Automation Award (IEEE 1999), Award of Merit (IFToMM 2004), 紫綬褒 章 (2006), エンゲルバーガー賞（2009）など受賞. 主な著作は,「口 ボット工学」(裳華房),「生物機械工学」(工業調査会),「Biologically Inspired Robots」(Oxford University Press, 1993) など.

(日本ロボット学会正会員)

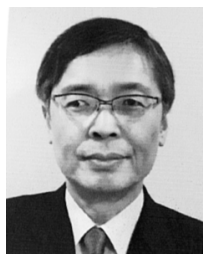

田窪敏夫（Toshio Takubo）

1978 年東北大学医学部卒業. 同年東京女子医科大学 第一内科入局（1988 年～1990 年 McGill University, Montreal, Canada に留学). 1992 年同大学 講師，現在に至る。呼吸生理学，呼吸不全に関する 研究に従事. 博士 (医学). 